EIto:

Douglas K. McCormick

\section{Restren Eortor}

Harvey Bialy

\section{SEHon musos}

Jennifer Van Brunt

Arthur Klausner

commanum Enoses

Peter Newmark

Jeffrey L. Fox

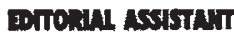

Caroline Schneider

Procuction munces

Donna Zuckerman

\section{Punsen:}

Gary M. Rekstad

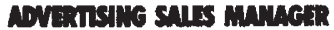

George F. Cominsky

\section{monopen abemsins}

SIIs mMACR

Hilary Turnbull

PULPUMaT MaMAGR

W. Paige Beaver

EDITORIAI CORRESPONDENCE:

BIO/TECHNOLOGY 65 Bleecker St., New York, NY 10012. Telephone: (212) 477-9600. Telex: $668497 \mathrm{UW}$ BIO/TECHNOLOGY, 4 Little Essex Street, London WC2R 3LF. Telephone: (01) 8366633 . Telex: 262024.

\section{SCIEWTIFIC ADVISORY BOARD}

\section{CHAIRMAN}

George Poste, Smith Kline \& French Pharmaceutical Development

Mary-Dell Chilton, CIBA-Geigy

Plant Molecular Biology

Carlo Croce, Wistar Institute

Monoclonal Antibodies

Arnold Demain, MIT

Secondary Metabolism and Fermentation

Stanley Falkow, Stanford

Medicine and Vaccine Development

David Goeddel, Genentech

Recombinant DNA Products

Benjamin Hall, Univ. of Washington Yeast Genetics

Ernest Jaworski, Monsanto

Plant Biotechnology

Ephraim Katchalski-Katzir

Tel Aviv University

Immobilized Enzymes and Polymers

Allen Laskin, N.J. Center for Advanced

Biotechnology and Medicine

Hydrocarbons and Polysaccharides

Malcolm Lilly, University College

London, Biochemical Engineering

David Mount, University of Arizona

Computer Applications

Carl-Gustaf Rosen, Alfa-Laval

Biochemical Engineering

Yukio Sugino, Takeda

Cancer Chemotherapy

Lemuel B. Wingard, University of Pittsburgh, Enzyme Engineering and Biosensors

To supplement coverage of Japanese develop ments, BIO/TECHNOLOGY has an editorial liaison with the editorial staff of Japan Chemical liaison with the editorial staff of Japan Ch
Daily, Ltd, and Japan Chemical Week.

\section{THE FIRST
wORLDS COLIDE}

[T]he new technological possibilities which have opened up in the field of biomedicine require the intervention of the political authorities and of the legislator since an uncontrolled application of such techniques could lead to unforeseeable and damaging consequences for civil society. Recourse to the conscience of each individual and to the self-regulation of researchers cannot be sufficient for insuring respect for personal rights and public order. If the legislator responsible for the common good were not watchful, he could be deprived of his prerogatives by researchers claiming to govern humanity in the name of biological discoveries and the alleged "improvement" processes which they would draw from those discoveries. "Eugenism" and forms of discrimination between human beings could come to be legitimized.

Deally? We are grateful to discover that biomedical research aspires to Roppression, world domination, and Mengelean eugenics. And it is extremely edifying to learn, after all this time, that "unforeseeable and damaging" are the inevitable concomitants of "consequences."

Thus begins the penultimate section of Instruction on Respect for Human Life in its Origin and on the Dignity of Procreation: Replies to Certain Questions of the Day, a position paper issued March 10 by the Congregation for the Doctrine of the Faith, the Vatican's theological equivalent of the U.S. Congress's Office of Technology Assessment.

Most of the paper concerns reproductive issues related to the biotechnologies tangentially, if at all: surrogate motherhood, artificial insemination, in vitro fertilization, and the like. (In general, the church is against them.) But other sections directly address-and in effect, denounce-researches into human developmental biology, gene therapy, and some possible therapies for central-nervous-system diseases: Among other things, the Vatican whitepaper seems to condemn all use of fetal tissue in research or therapy, and any therapy-especially any genetic alteration-not intended expressly and solely to benefit the unborn subject.

These Roman no's contrast sharply with another report from the biomedical researchers themselves. If the Vatican instruction is notable for its 1984boding, The Bristol-Myers Report: Medicine in the Next Century, a poll of scientific opinion released March 4 by Louis Harris and Associates (New York), is disturbing only in its caution. For the most part, the only surprise is the lack of surprises in the responses of the 227 prominent scientists ( 21 of them "biotechnology scientists") asked to consult their sometimes refractory crystal balls to predict the state of medicine at the turn of the millennium.

True, 90 percent of the 29 neuroscientists interviewed did expect that transplants of fetal brain tissue should be an accepted therapy for certain disorders of the brain. (This is one of those queasy areas that the Congregation for the Doctrine of the Faith's instruction would seem to rule out, and indeed, only 79 percent of the researchers interviewed said that such transplants probably would be accepted.)

More remarkable was the researchers' devotion to conventional wisdom. The result is broad, but shallow. For example, a plurality of the 227 interviewees cited cancer therapy as the area most likely to benefit from genetic engineering by the year 2000 , while the subset of "biotechnology scientists" was bullish about genetically engineered vaccines (88 percent expected a "much" or "moderate" impact on treatment), t-PA (64 percent), and Factor VIII (67 percent). Even here, though, caution was the watchword. For example, although recombinant vaccines for hepatitis, malaria, and cholera are pretty much in hand, some two-thirds of the biotechnologists expected these new tools to yield only moderate or slight improvement in preventing or treating these diseases.

Both reports deserve study. The Vatican position paper is profound but narrow; it dances on the head of a pin and touches biotechnology as if by accident. The Bristol-Myers report is broad but shallow. Yet, in their small overlapping volume, the two views of biomedical research conflict sharply.

Can we reconcile such differences, each with its own large, ready-made following? Or are the research establishment and the religious establishment irreconcilable juggernauts, bound for collision as the new millennium begins, a little over thirteen years from now?
-Douglas McCormick 